\title{
Microbacterium deminutum sp. nov., Microbacterium pumilum sp. nov. and Microbacterium aoyamense sp. nov.
}

\author{
Correspondence \\ Yoko Takahashi \\ ytakaha@lisci.kitasato-u.ac.jp
}

\author{
Akiko Kageyama, ${ }^{1}$ Yoko Takahashi ${ }^{1}$ and Satoshi Ōmura ${ }^{1,2}$ \\ ${ }^{1}$ Kitasato Institute for Life Sciences, Kitasato University, 5-9-1 Shirokane, Minato-ku, Tokyo \\ 108-8641, Japan \\ ${ }^{2}$ The Kitasato Institute, 5-9-1 Shirokane, Minato-ku, Tokyo 108-8641, Japan
}

\begin{abstract}
Three novel bacterial strains were isolated from a soil sample collected in Japan by culture on a GPM agar plate supplemented with superoxide dismutase and catalase. The strains were Gram-positive, catalase-positive, non-motile bacteria with L-ornithine as a diagnostic diamino acid of the peptidoglycan. The acyl type of the peptidoglycan was $N$-glycolyl. The major menaquinones were MK-12, 13 and 14. Mycolic acids were not detected. $G+C$ contents of the DNA were in the range 69-71 mol\%. Comparative 16S rRNA gene sequence analysis revealed that the isolates belonged to the genus Microbacterium and were closely related to Microbacterium terregens, Microbacterium aurum, Microbacterium koreense, Microbacterium schleiferi and Microbacterium lacticum. However, M. aurum, M. koreense and M. lacticum clearly differed from the isolated strains based on the presence of L-lysine as the cell-wall diamino acid and various other chemotaxonomic characteristics. Levels of DNA-DNA relatedness showed that the isolated strains represented three separate genomic species. Based on both phenotypic and genotypic data, the following novel species of the genus Microbacterium are proposed: Microbacterium deminutum sp. nov. (type strain KV-483 ${ }^{\top}=$ NRRL B-24453 ${ }^{\top}=$ NBRC $101278^{\top}$ ), Microbacterium pumilum sp. nov. (type strain KV-488 ${ }^{\top}=\mathrm{NRRL} B-24452^{\top}=\mathrm{NBRC} 101279^{\top}$ ) and Microbacterium aoyamense sp. nov. (type strain KV-492 ${ }^{\top}=\mathrm{NRRL} \mathrm{B}-24451^{\top}=\mathrm{NBRC} 101280^{\top}$ ).
\end{abstract}

The genus Microbacterium was proposed by Orla-Jensen (1919) with the type species Microbacterium lacticum, and the description was emended by Takeuchi \& Hatano (1998). Members of the genus are widespread and have been isolated from various environmental habitats (Collins \& Bradbury, 1992). At the time of writing, the genus Microbacterium comprises 40 recognized species.

Strains $\mathrm{KV}-483^{\mathrm{T}}, \mathrm{KV}-488^{\mathrm{T}}$ and $\mathrm{KV}-492^{\mathrm{T}}$ were isolated from a soil sample collected from a cemetery in Aoyama, Tokyo, Japan. Two grams of soil was suspended in $18 \mathrm{ml}$ sterile water and mixed. Soil particles were allowed to sediment, the liquid phase was diluted $10^{5}$-fold and $100 \mu \mathrm{l}$ samples were spread onto the surface of each cultivation plate. GPM agar plates with superoxide dismutase (300 U per plate) and catalase (2100 U per plate) (Takahashi et al., 2003) were used, and were cultured at $27^{\circ} \mathrm{C}$. Biomass for biochemical and chemotaxonomic characterization was prepared by

The GenBank/EMBL/DDBJ accession numbers for the $16 \mathrm{~S}$ rRNA gene sequences of strains $\mathrm{KV}-483^{\top}, \mathrm{KV}-488^{\top}$ and $\mathrm{KV}-492^{\top}$ are AB234026-AB234028.

DNA-DNA relatedness values among strains $\mathrm{KV}-483^{\top}, \mathrm{KV}-488^{\top}$ and $\mathrm{KV}-492^{\top}$ and related Microbacterium type strains are available as supplementary material in IJSEM Online. culturing in trypticase soy broth at $27^{\circ} \mathrm{C}$ followed by cell harvesting by centrifugation.

Morphological observation under a scanning electron microscope (model JSM-5600; JEOL) was performed on cultures grown on GPM medium at $27^{\circ} \mathrm{C}$ for 6 or 7 days. Assimilation of carbon sources was determined using agar medium of yeast nitrogen base without amino acids (Nihon Pharmaceutical Co., Ltd) (Pridham \& Gottlieb, 1948). $\mathrm{NaCl}$ tolerance and $\mathrm{pH}$ and temperature ranges for growth were determined on one-fifth-strength nutrient agar. The three new isolates and reference strains Microbacterium aurum JCM $9179^{\mathrm{T}}$, Microbacterium schleiferi JCM $9175^{\mathrm{T}}$ and Microbacterium terregens JCM $1342^{\mathrm{T}}$ were characterized biochemically by using the API ZYM system according to the manufacturer's instructions (bioMérieux).

$N$-Acyl types of muramic acid were determined using the method of Uchida \& Aida (1977). Purified cell wall was obtained by the method of Kawamoto et al. (1981). One milligram of purified cell wall was hydrolysed at $100{ }^{\circ} \mathrm{C}$ with $1 \mathrm{ml} 6 \mathrm{M} \mathrm{HCl}$ for $16 \mathrm{~h}$. The residue was dissolved in $100 \mu \mathrm{l}$ water and was used for amino acid analysis. Composition of amino acids was determined by HPLC using the Pico Tag method (Waters). This method involves the use of 
phenylisothiocyanate for creation of phenylthiocarbamyl derivatives. Cell-wall sugars were obtained according to the method of Kawamoto et al. (1981), and samples were analysed by using the method of Becker et al. (1965); the presence of mycolic acid was examined by the TLC method of Tomiyasu (1982). Menaquinones were extracted and purified according to the method of Collins et al. (1977), and were then analysed by HPLC (model 802-SC; Jasco) on a chromatograph equipped with a CAPCELL PAK C18 column (Shiseido) (Tamaoka et al., 1983). Methyl esters of cellular fatty acids were prepared by direct transmethylation with methanolic hydrochloric acid. They were then analysed by GLC (model GC-17A; Shimazu) with a DB23 capillary column $(0.25 \mathrm{~mm} \times 30 \mathrm{~m}$; J\&W Scientific) (Suzuki \& Komagata, 1983). Cells grown for 3 or 4 days were collected and used for these experiments.

DNA was isolated as described by Saito \& Miura (1983). DNA base composition was estimated by HPLC (Tamaoka \& Komagata, 1984). Levels of DNA-DNA relatedness were determined according to the method of Ezaki et al. (1989) using photobiotin and a microplate format.

For 16S rRNA gene sequence analysis, DNA was prepared and amplified as reported by Yu et al. (2002) and Takahashi et al. (2003), respectively, and the gene was sequenced with an automatic analyser (ABI PRISM 377A; PE Applied Biosystems) using a PRISM Ready Reaction dye primer cycle sequencing kit (PE Applied Biosystems). Species related closely to those of the new isolates were determined by performing sequence database searches using the BLAST program. Sequence data for related species were retrieved from GenBank. Phylogenetic analysis was performed using CLUSTAL W software (Thompson et al., 1994). Nucleotide substitution rates ( $K_{\text {nuc }}$ values) were calculated (Kimura \& Ohta, 1972) and phylogenetic trees were constructed by using the neighbour-joining method (Saitou \& Nei, 1987). Sequence similarity values were determined by visual comparison and manual calculation.

Cells of strains $\mathrm{KV}-483^{\mathrm{T}}, \mathrm{KV}-488^{\mathrm{T}}$ and $\mathrm{KV}-492^{\mathrm{T}}$ were irregular rods, with cell size in the range $0 \cdot 2-0 \cdot 7 \times 0 \cdot 4-1 \cdot 2 \mu \mathrm{m}$. Cells of all three strains were Gram-positive, catalasepositive and non-motile. The DNA G $+\mathrm{C}$ content of the three strains was in the range $69-71 \mathrm{~mol} \%$. Cell-wall peptidoglycans of KV- $483^{\mathrm{T}}, \mathrm{KV}-488^{\mathrm{T}}$ and $\mathrm{KV}-492^{\mathrm{T}}$ contained glycine, homoserine, glutamic acid, 3-hydroxyglutamic acid, ornithine and alanine. The predominant menaquinones were MK-12, MK-13 and MK-14, with ratios of $14: 50: 9$ for KV $-483^{\mathrm{T}}, 6: 10: 3$ for KV $-488^{\mathrm{T}}$ and $7: 60: 9$ for $\mathrm{KV}-492^{\mathrm{T}}$. The acyl type of the peptidoglycan was $\mathrm{N}$ glycolyl. Mycolic acids were not detected. The predominant cellular fatty acid components were anteiso- $\mathrm{C}_{15: 0}$, anteiso$\mathrm{C}_{17: 0}$ and iso- $\mathrm{C}_{16: 0}$ (Table 1).

Nearly complete 16S rRNA gene sequences were determined for the three isolated strains. Phylogenetic analysis based on these sequences demonstrated that the three strains belonged to the genus Microbacterium. Fig. 1 shows
Table 1. Fatty acid compositions of the novel strains

Data are percentages of the total fatty acids. -, Not detected or $<1 \%$.

\begin{tabular}{|c|c|c|c|}
\hline Fatty acid & $\mathrm{KV}-483^{\mathrm{T}}$ & $\mathrm{KV}-488^{\mathrm{T}}$ & $\mathrm{KV}-492^{\mathrm{T}}$ \\
\hline iso- $\mathrm{C}_{14: 0}$ & - & $1 \cdot 07$ & $1 \cdot 05$ \\
\hline iso- $\mathrm{C}_{15: 0}$ & - & $3 \cdot 37$ & $8 \cdot 91$ \\
\hline anteiso- $\mathrm{C}_{15: 0}$ & $28 \cdot 3$ & $46 \cdot 61$ & $48 \cdot 2$ \\
\hline iso- $\mathrm{C}_{16: 0}$ & $7 \cdot 04$ & $25 \cdot 92$ & $17 \cdot 2$ \\
\hline $\mathrm{C}_{16: 0}$ & $2 \cdot 88$ & $2 \cdot 33$ & $1 \cdot 15$ \\
\hline iso- $\mathrm{C}_{17: 0}$ & $1 \cdot 57$ & $4 \cdot 98$ & $2 \cdot 28$ \\
\hline anteiso- $\mathrm{C}_{17: 0}$ & $58 \cdot 9$ & $10 \cdot 20$ & $21 \cdot 3$ \\
\hline iso- $\mathrm{C}_{18: 0}$ & - & $1 \cdot 90$ & - \\
\hline $\mathrm{C}_{18: 0}$ & - & $2 \cdot 88$ & - \\
\hline
\end{tabular}

the relationship between the three novel strains and their nearest phylogenetic relatives. $16 \mathrm{~S}$ rRNA gene sequencing based on the $1433 \mathrm{bp}$ of strain KV- $483^{\mathrm{T}}$ revealed peak similarity levels of $98.8 \%$ with the sequence of $M$. terregens IFO $12961^{\mathrm{T}}$ (Takeuchi \& Hatano, 1998) and $98.5 \%$ with that of M. schleiferi DSM 20489 ${ }^{\mathrm{T}}$ (Yokota et al., 1993b). Strain $\mathrm{KV}-488^{\mathrm{T}}$ (1359 bp) showed peak similarities of $98.9 \%$ with the $16 \mathrm{~S}$ rRNA gene sequence of $M$. terregens IFO $12961^{\mathrm{T}}$ and $98.7 \%$ with that of M. aurum DSM $8600^{\mathrm{T}}$ (Yokota et al., 1993a). Strain KV- $492^{\mathrm{T}}$ (1443 bp) had peak similarity levels of $99 \cdot 1 \%$ with $M$. terregens IFO $12961^{\mathrm{T}}$ and $98 \cdot 9 \%$ with M. aurum DSM $8600^{\mathrm{T}}$. 16S rRNA gene sequence similarity values among the three novel strains were $98 \cdot 8-99 \cdot 8 \%$.

Levels of DNA-DNA hybridization were determined from duplicate experiments with the three novel strains and their

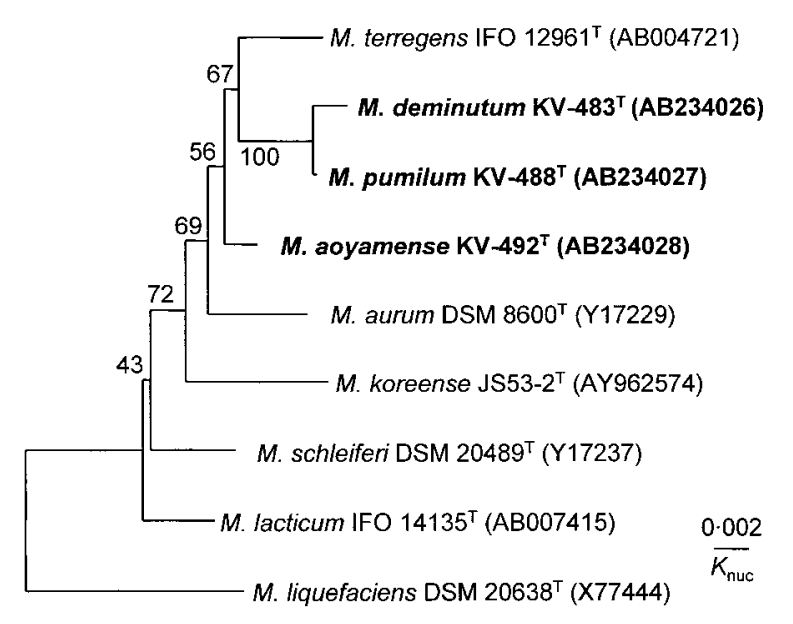

Fig. 1. Phylogenetic tree derived from 16S rRNA gene sequences created using the neighbour-joining method and $K_{\text {nuc }}$ values, showing the phylogenetic positions of strains KV$483^{\top}, \mathrm{KV}-488^{\top}$ and $\mathrm{KV}-492^{\top}$. Numbers at branch points are bootstrap percentages (based on 1000 resamplings). The tree was unrooted and Microbacterium liquefaciens DSM $20638^{\top}$ was used as an outgroup. 
three closest phylogenetic relatives. Representative values among strains $\mathrm{KV}-483^{\mathrm{T}}, \mathrm{KV}-488^{\mathrm{T}}$ and $\mathrm{KV}-492^{\mathrm{T}}$ and the type strains of $M$. aurum, $M$. schleiferi and $M$. terregens were less than $29 \%$ (see Supplementary Table S1 in IJSEM Online). These values were well below the $70 \%$ cut-off point for species classification recommended by Wayne et al. (1987).

The morphological and chemotaxonomic characteristics (Tables 1 and 2) of the isolated strains are consistent with their assignment to the genus Microbacterium (Takeuchi \& Hatano, 1998). A number of phenotypic characteristics that can be used to distinguish the isolated strains from each other and from their nearest phylogenetic neighbours are presented in Table 2.

From the phenotypic and genotypic data presented, it is apparent that these isolated strains represent three distinct species within the genus Microbacterium. We propose the names Microbacterium deminutum sp. nov., Microbacterium pumilum sp. nov. and Microbacterium aoyamense sp. nov.

\section{Description of Microbacterium deminutum sp. nov.}

Microbacterium deminutum (de.mi.nu'tum. L. part. adj. deminutum diminutive).

Cells are irregular rods, $0 \cdot 3-0 \cdot 7 \times 0 \cdot 5-0 \cdot 9 \mu \mathrm{m}$ in size. Gram-positive, non-motile, catalase-positive and aerobic. Colonies are pale yellow. Growth occurs at $\mathrm{pH}$ 6-9 and $17-31{ }^{\circ} \mathrm{C}$. In one-fifth-strength nutrient agar medium, $\mathrm{NaCl}$ is tolerated up to $4 \%$. Glucose, galactose, maltose, mannose, rhamnose and sucrose are assimilated, but arabinose, fructose, mannitol, raffinose, trehalose and xylose are not. Esterase (C4), esterase lipase (C8), leucine arylamidase, valine arylamidase, cystine arylamidase, trypsin, chymotrypsin, acid phosphatase, naphthol-AS-BI-phosphohydrolase, $\alpha$-galactosidase, $\beta$-galactosidase, $\beta$-glucuronidase, $\alpha$-glucosidase, $\beta$-glucosidase and $N$-acetyl- $\beta$-glucosamidase are detected with the API ZYM enzyme assay; $\alpha$-fucosidase is not detected. Weak reactions for alkaline phosphatase, lipase $(\mathrm{C} 14)$ and $\alpha$-mannosidase are detected. The diagnostic diamino acid of the peptidoglycan is L-ornithine. The acyl type of the peptidoglycan is $N$-glycolyl. Major menaquinones are MK-12, 13 and 14. Major cellular fatty acids are anteiso- $\mathrm{C}_{15: 0}$, anteiso- $\mathrm{C}_{17: 0}$ and iso- $\mathrm{C}_{16: 0}$. Cellwall sugars contain rhamnose, fucose, galactose, glucose and xylose. The DNA G + C content is $69 \mathrm{~mol} \%$.

The type strain, KV-483 ${ }^{\mathrm{T}} \quad$ (=NRRL $\mathrm{B}-24453^{\mathrm{T}}=\mathrm{NBRC}$ $101278^{\mathrm{T}}$ ), was isolated from soil from Aoyamareien, Tokyo, Japan.

\section{Description of Microbacterium pumilum sp. nov.}

Microbacterium pumilum (pu'mi.lum. L. neut. adj. pumilum dwarfish, diminutive, little).
Cells are irregular rods, $0 \cdot 2-0.6 \times 0 \cdot 4-1 \cdot 2 \mu \mathrm{m}$ in size. Gram-positive, non-motile, catalase-positive and aerobic. Colonies are pale yellow. Growth occurs at $\mathrm{pH} 7-10$ and $17-32{ }^{\circ} \mathrm{C}$. In one-fifth-strength nutrient agar medium, $\mathrm{NaCl}$ is tolerated up to $2 \%$. Glucose, arabinose, galactose, maltose, mannose and sucrose are assimilated, but fructose, mannitol, raffinose, rhamnose, trehalose and xylose are not. Alkaline phosphatase, esterase lipase (C8), leucine arylamidase, valine arylamidase, cystine arylamidase, trypsin, chymotrypsin, acid phosphatase, naphthol-ASBI-phosphohydrolase, $\alpha$-galactosidase, $\beta$-galactosidase, $\beta$-glucuronidase, $\alpha$-glucosidase, $\beta$-glucosidase, $N$-acetyl- $\beta$ glucosamidase and $\alpha$-fucosidase are detected with the API ZYM enzyme assay; $\alpha$-mannosidase is not detected. Weak reactions for esterase $(\mathrm{C} 4)$ and lipase $(\mathrm{C} 14)$ are detected. The diagnostic diamino acid of the peptidoglycan is L-ornithine. The acyl type of the peptidoglycan is $N$-glycolyl. Major menaquinones are $\mathrm{MK}-12,13$ and 14. Major cellular fatty acids are anteiso- $\mathrm{C}_{15: 0}$, anteiso- $\mathrm{C}_{17: 0}$ and iso- $\mathrm{C}_{16: 0}$. Cellwall sugars contain rhamnose and galactose. The DNA $\mathrm{G}+\mathrm{C}$ content is $71 \mathrm{~mol} \%$.

The type strain, KV- $488^{\mathrm{T}} \quad\left(=\mathrm{NRRL} \quad \mathrm{B}-24452^{\mathrm{T}}=\mathrm{NBRC}\right.$ $101279^{\mathrm{T}}$ ), was isolated from soil from Aoyamareien, Tokyo, Japan.

\section{Description of Microbacterium aoyamense sp. nov.}

Microbacterium aoyamense (ao.ya.men'se. N.L. neut. adj. aoyamense referring to Aoyama, Tokyo, Japan, where the type strain was isolated).

Cells are irregular rods, $0 \cdot 3-0 \cdot 5 \times 0 \cdot 4-0 \cdot 8 \mu \mathrm{m}$ in size. Gram-positive, non-motile, catalase-positive and aerobic. Colonies are pale yellow. Growth occurs at pH 5-11 and $14-34{ }^{\circ} \mathrm{C}$. In one-fifth-strength nutrient agar medium, $\mathrm{NaCl}$ is tolerated up to $5 \%$. Glucose, galactose, maltose, mannitol, mannose, raffinose, rhamnose, sucrose and trehalose are assimilated, but arabinose, fructose and xylose are not. Esterase (C4), esterase lipase (C8), lipase (C14), leucine arylamidase, acid phosphatase, naphthol-AS-BI-phosphohydrolase, $\beta$-galactosidase, $\alpha$-glucosidase, $\beta$-glucosidase and $N$-acetyl- $\beta$-glucosamidase are detected with the API ZYM enzyme assay; alkaline phosphatase, cystine arylamidase, trypsin, chymotrypsin, $\alpha$-galactosidase, $\beta$-glucuronidase, $\alpha$-mannosidase and $\alpha$-fucosidase are negative. Weak reaction for valine arylamidase. The diagnostic diamino acid of the peptidoglycan is L-ornithine. The acyl type of the peptidoglycan is $\mathrm{N}$-glycolyl. Major menaquinones are MK-12, 13 and 14. Major cellular fatty acids are anteiso$\mathrm{C}_{15: 0}$, anteiso- $\mathrm{C}_{17: 0}$ and iso- $\mathrm{C}_{16: 0}$. Cell-wall sugars contain rhamnose, galactose and xylose. The DNA G+C content is $69 \mathrm{~mol} \%$.

The type strain, KV- $492^{\mathrm{T}}$ (=NRRL $\mathrm{B}-24451^{\mathrm{T}}=\mathrm{NBRC}$ $101280^{\mathrm{T}}$ ), was isolated from soil from Aoyamareien, Tokyo, Japan. 
Table 2. Differential characteristics of strains $\mathrm{KV}-483^{\top}, \mathrm{KV}-488^{\top}$ and $\mathrm{KV}-492^{\top}$ and related Microbacterium species

Taxa: 1, KV-483 $3^{\mathrm{T}} ; 2, \mathrm{KV}-488^{\mathrm{T}} ; 3, \mathrm{KV}-492^{\mathrm{T}} ; 4$, M. aurum JCM $9179^{\mathrm{T}} ; 5$, M. terregens JCM $1342^{\mathrm{T}} ; 6$, M. schleiferi JCM $9175^{\mathrm{T}} ; 7$, M. koreense. In addition to the displayed differential characteristics, strain $\mathrm{KV}-488^{\mathrm{T}}$ differs from $\mathrm{KV}-483^{\mathrm{T}}$ and $\mathrm{KV}-492^{\mathrm{T}}$ in assimilation of L-arabinose and inability to assimilate L-rhamnose as a sole carbon source. Data for the type strains of M. aurum, M. terregens and M. schleiferi are from this study (API ZYM tests), Lee et al. (2006) (assimilation of carbon sources) and Takeuchi \& Hatano (1998) and Behrendt et al. (2001) (chemotaxonomic characteristics and growth at $37^{\circ} \mathrm{C}$ ). Data for M. koreense are from Lee et al. (2006). +, Positive; W, weakly positive; -, negative; ND, no data.

\begin{tabular}{|c|c|c|c|c|c|c|c|}
\hline Characteristic & 1 & 2 & 3 & 4 & 5 & 6 & 7 \\
\hline Growth at $37^{\circ} \mathrm{C}$ & - & - & - & + & - & + & + \\
\hline \multicolumn{8}{|l|}{ Assimilation of: } \\
\hline Glucose & + & + & + & + & - & - & + \\
\hline Mannitol & - & - & + & + & - & - & + \\
\hline Maltose & + & + & + & + & - & - & + \\
\hline Mannose & + & + & + & + & - & - & + \\
\hline \multicolumn{8}{|c|}{ Enzyme assay (API ZYM) results: } \\
\hline Alkaline phosphatase & $\mathrm{W}$ & + & - & $\mathrm{w}$ & $\mathrm{W}$ & - & $\mathrm{ND}$ \\
\hline Valine arylamidase & + & + & $\mathrm{W}$ & + & + & + & ND \\
\hline Cystine arylamidase & + & + & - & + & + & $\mathrm{W}$ & $\mathrm{ND}$ \\
\hline Trypsin & + & + & - & + & $\mathrm{W}$ & + & $\mathrm{ND}$ \\
\hline$\alpha$-Galactosidase & + & + & - & + & - & - & $\mathrm{ND}$ \\
\hline$\beta$-Galactosidase & + & + & + & + & - & + & ND \\
\hline$\beta$-Glucuronidase & + & + & - & - & - & $\mathrm{W}$ & ND \\
\hline$N$-Acetyl- $\beta$-glucosamidase & + & + & + & - & + & + & $\mathrm{ND}$ \\
\hline$\alpha$-Mannosidase & $\mathrm{w}$ & - & - & + & - & - & $\mathrm{ND}$ \\
\hline DNA G $+\mathrm{C}$ content $(\mathrm{mol} \%)$ & 69 & 71 & 69 & 69 & 69 & 67 & 68 \\
\hline Cell-wall diamino acid ${ }^{\star}$ & Orn & Orn & Orn & Lys & Orn & Orn & Lys \\
\hline Cell-wall sugars $\dagger$ & Rha, Fuc, Gal, Glc, Xyl & Rha, Gal & Rha, Gal, Xyl & Fuc, Gal, Glc & Rha, Gal, 6dTal & 6dTal, Man, Gal & Gal, Xyl \\
\hline Major menaquinones (ratio) & $12,13,14(14: 50: 9)$ & $12,13,14(6: 10: 3)$ & $12,13,14(7: 60: 9)$ & 11,12 & 12,13 & $10,11,12$ & 11,12 \\
\hline Major fatty acids $\ddagger$ & ai17, ai15, i16 & ai15, i16, ai17 & ai15, ai17, i16 & ai15, ai17, i16 & ai15, ai17, i16 & ai15, ai17, i16 & ai15, ai17, i16 \\
\hline
\end{tabular}

${ }^{\star}$ Lys, Lysine; Orn, ornithine.

$\lceil 6 \mathrm{dTal}$, 6-Deoxytalose; Fuc, fucose; Gal, galactose; Glc, glucose; Man, mannose; Rha, rhamnose; Xyl, xylose.

‡ai, Anteiso; i, iso. All fatty acids listed are saturated. 


\section{Acknowledgements}

This study was supported in part by a grant from the 21st Century COE Program, Ministry of Education, Culture, Sports, Science and Technology (MEXT). Dr Masato Iwatsuki is kindly acknowledged for his help with analysis of cell-wall amino acid composition.

\section{References}

Becker, B., Lechevalier, M. P. \& Lechevalier, H. A. (1965). Chemical composition of cell-wall preparation from strains of various formgenera of aerobic actinomycetes. Appl Microbiol 13, 236-243.

Behrendt, U., Ulrich, A. \& Schumann, P. (2001). Description of Microbacterium foliorum sp. nov. and Microbacterium phyllosphaerae sp. nov., isolated from the phyllosphere of grasses and the surface litter after mulching the sward, and reclassification of Aureobacterium resistens (Funke et al. 1998) as Microbacterium resistens comb. nov. Int J Syst Evol Microbiol 51, 1267-1276.

Collins, M. D. \& Bradbury, J. F. (1992). The genera Agromyces, Aureobacterium, Clavibacter, Curtobacterium, and Microbacterium. In The Prokaryotes, 2nd edn, pp. 1355-1368. Edited by A. Balows, H. G. Trüper, M. Dworkin, W. Harder \& K. H. Schleifer. Berlin: Springer.

Collins, M. D., Pirouz, T., Goodfellow, M. \& Minnikin, D. E. (1977). Distribution of menaquinones in actinomycetes and corynebacteria. J Gen Microbiol 100, 221-230.

Ezaki, T., Hashimoto, Y. \& Yabuuchi, E. (1989). Fluorometric deoxyribonucleic acid-deoxyribonucleic acid hybridization in microdilution wells as an alternative to membrane filter hybridization in which radioisotopes are used to determine genetic relatedness among bacterial strains. Int J Syst Bacteriol 39, 224-229.

Kawamoto, I., Oka, T. \& Nara, T. (1981). Cell wall composition of Micromonospora olivoasterospora, Micromonospora sagamiensis, and related organisms. J Bacteriol 146, 527-534.

Kimura, M. \& Ohta, T. (1972). On the stochastic model for estimation of mutation distance between homologous proteins. J Mol Evol 2, 87-90.

Lee, J. S., Lee, K. C. \& Park, Y. H. (2006). Microbacterium koreense sp. nov., from sea water in the South Sea of Korea. Int J Syst Evol Microbiol 56, 423-427.

Orla-Jensen, S. (1919). The Lactic Acid Bacteria. Copenhagen: Host \& Sons.

Pridham, T. G. \& Gottlieb, D. (1948). The utilization of carbon compounds by some Actinomycetales as an aid for species determination. $J$ Bacteriol 56, 107-114.
Saito, H. \& Miura, K. (1983). Preparation of transforming deoxyribonucleic acid by phenol treatment. Biochim Biophys Acta 72, 619-629.

Saitou, N. \& Nei, M. (1987). The neighbor-joining method: a new method for reconstructing phylogenetic trees. Mol Biol Evol 4, 406-425.

Suzuki, K. \& Komagata, K. (1983). Taxonomic significance of cellular fatty acid composition in some coryneform bacteria. Int J Syst Bacteriol 33, 188-200.

Takahashi, Y., Katoh, S., Shikura, N., Tomoda, H. \& Omura, S. (2003). Superoxide dismutase produced by soil bacteria increases bacterial colony growth from soil samples. J Gen Appl Microbiol 49, 263-266.

Takeuchi, M. \& Hatano, K. (1998). Union of the genera Microbacterium Orla-Jensen and Aureobacterium Collins et al. in a redefined genus Microbacterium. Int J Syst Bacteriol 48, 739-747.

Tamaoka, J. \& Komagata, K. (1984). Determination of DNA base composition by reversed-phase high-performance liquid chromatography. FEMS Microbiol Lett 25, 125-128.

Tamaoka, J., Katayama-Fujimura, Y. \& Kuraishi, H. (1983). Analysis of bacterial menaquinone mixtures by high performance liquid chromatography. J Appl Bacteriol 54, 31-36.

Thompson, J. D., Higgins, D. G. \& Gibson, T. J. (1994). CLUSTAL W: improving the sensitivity of progressive multiple sequence alignment through sequence weighting, position-specific gap penalties and weight matrix choice. Nucleic Acids Res 22, 4673-4680.

Tomiyasu, I. (1982). Mycolic acid composition and thermally adaptive changes in Nocardia asteroids. J Bacteriol 151, 828-837.

Uchida, K. \& Aida, K. (1977). Acyl type of bacterial cell wall: its simple identification by a colorimetric method. J Gen Appl Microbiol 23, 249-260.

Wayne, L. G., Brenner, D. J., Colwell, R. R. \& 9 other authors (1987). Report of the ad hoc committee on reconciliation of approaches to bacterial systematics. Int J Syst Bacteriol 37, 463-464.

Yokota, A., Takeuchi, M. \& Weiss, N. (1993a). Proposal of two new species in the genus Microbacterium: Microbacterium dextranolyticum sp. nov. and Microbacterium aurum sp. nov. Int J Syst Bacteriol 43, 549-554.

Yokota, A., Takeuchi, M., Sakane, T. \& Weiss, N. (1993b). Proposal of six new species in the genus Aureobacterium and transfer of Flavobacterium esteraromaticum Omelicanski to the genus Aureobacterium as Aureobacterium esteraromaticum comb. nov. Int J Syst Bacteriol 43, 555-564.

Yu, L., Takahashi, Y., Matsumoto, A., Seino, A., Iwai, Y. \& Omura, S. (2002). Application of PCR for selection of gram-positive bacteria with high DNA $\mathrm{G}+\mathrm{C}$ content among new isolates. Actinomycetologica 16, 1-5. 